\title{
'The Girl Who Was Chased by Fire': Violence and Passion in Contemporary Swedish Fascist Fiction
}

\author{
Mattias Gardell \\ Centre for Multidisciplinary Studies of Racism, Uppsala University, \\ Uppsala, Sweden \\ mattias.gardell@cemfor.uu.se
}

\begin{abstract}
Fascism invites its adherents to be part of something greater than themselves, invoking their longing for honor and glory, passion and heroism. An important avenue for articulating its affective dimension is cultural production. This article investigates the role of violence and passion in contemporary Swedish-language fascist fiction. The protagonist is typically a young white man or woman who wakes up to the realities of the ongoing white genocide through being exposed to violent crime committed by racialized aliens protected by the System. Seeking revenge, the protagonist learns how to be a man or meets her hero, and is introduced to fascist ideology and the art of killing. Fascist literature identifies aggression and ethnical cleansing as altruistic acts of love. With its passionate celebration of violence, fascism hails the productivity of destructivity, and the life-bequeathing aspects of death, which is at the core of fascism's urge for national rebirth.
\end{abstract}

\section{Keywords}

Sweden - fascist culture - fascist fiction - violence - heroism - death - love - radical nationalism

Fascism - here used in its Griffian sense as a generic term for revolutionary nationalisms centered on a mythic core of national rebirth - has a discernible affective dimension. It offers its adherents to be part of something greater than themselves, invoking their longing for glory, honor, and beauty, and inducing their capacities for hate, love, self-sacrifice, and violence. An important avenue 
for communicating fascist passion is cultural production: literature, music, film and art. Hitler, after all, was an artist, to whom the German Volkgeist was the spirit of art itself. 'Art, in the broadest possible sense', neoreactionary Dark Enlightenment thinker Curtis Yarvin (a.k.a. Mencius Moldbug) wrote in 2019, 'is the bloodless weapon that can replace the world. The world cannot be won by force. She must be seduced by greatness. ${ }^{2}$ Accordingly, culture, fine arts, literature, film, storytelling, may be as important to disseminating the worldview of contemporary fascism as the programs, rallies and election campaigns of the fascist political parties, at least for the time being.

In Rising From the Ruins (2017), intellectual historian, political philosopher, and alt-right identitarian fascist Joakim Andersen (a.k.a. Oskorei), discusses how his fellow fascists should best exploit the momentum they currently experience across the 'once white world' ${ }^{3}$ A cofounder of the identitarian think-tank Motpol [antipole/negation], Andersen has published extensively under the penname Oskorei, a reference to the Asgårdsreia, the Riders of Asgaard, a band of undead ancestral spirits associated with Odin in Norse mythology, and King Arthur in Brittany and Celtic legends, known in Gaelic, Slavic and Polish folklore as the Wild Hunt, and as Ghost Riders in North American folk tales and folk music.

Much like Julius Evola, whose postwar work Men Among Ruins (1953) Andersen refers to, ${ }^{4}$ Andersen does not primarily talk about physical ruins, but of the scattered immaterial foundations of Western civilization he sees around him. According to Andersen, classical white Western culture, with its alleged bond between Man, Society, Nature, and the Sacred, has fallen apart. The ancient ideals of honor, beauty, heroism, glory, blood, family, and nation, that supposedly upheld classical society, lie in debris by the pressure of numerous attacks from anti-white forces. Despite the material and economic growth of the global North, the cultural and intellectual ruins, the desert of Nietzsche and Baudrillard, is gradually expanding. Among the ruins of this haunted landscape of mental despair, the white man and woman wander aimlessly like

1 Eric Michaud, The Cult of Art in Nazi Germany (Stanford, CA: Stanford University Press, 2004), 16.

2 Curtis Yarvin, 'The Deep State vs. The Deep Right,' The American Mind, October 23, 2019, https://americanmind.org/features/conservatism-in-the-bronze-age/the-deep-statevs-the-deep-right/.

3 Joakim Andersen, Rising From the Ruins (London: Arktos, 2018).

4 Julius Evola, Men Among the Ruins: Postwar Reflections of a Radical Traditionalist (Rochester, Vermont: Inner Traditions, 2002). 
living dead, seeking in vain to satisfy their hunger in the great emptiness of mesmerizing material abundance. ${ }^{5}$

Borrowing from Antonio Gramsci, Andersen suggests that we are living in an interregnum between two stable orders: "The old is dying and the new cannot be born'. The old system of sovereign nation-states, in which responsible political administrations secured the wellbeing of their supposedly homogenous constituencies within their countries' secure territorial borders, is dying, and the global utopia of multiculturalism cannot be born. Fortress Europe is caving in, and entire European regions, cities and city quarters are transforming into alien islands of eerie nonwhiteness: 'Toto, I've got a feeling we're not in Kansas anymore'. The white bourgeoise is increasingly terrified. They drug themselves with consumption and seem ready to follow any anti-immigrant populist who promise to return things to normal. But there is no going back. The white world supremacy of the twentieth century is not returning. While white liberals and mainstream white conservatives see this as negative and frightening, white fascists should, Andersen argues, seize the opportunity to define the new order that will arise out of the ashes of the rapidly approaching Ragnarök [doom of the Gods] that will engulf the dying order. ${ }^{6}$

To define the becoming new order, Andersen stresses that 'the New Right' needs the synergies of full spectrum dominance: 'we need to control not only the street, but the Internet, the parliament as well as the academy', which requires 'the ability to divide labor. ${ }^{7}$ Hence the 'importance of metapolitics, of creating and maintaining alliances, disseminating our concepts, analyzing and making an accurate assessment of the common sense of the people, and targeting the weak spot of the opponent.' ${ }^{8}$ In this respect, Gramsci is to Andersen an indispensable teacher, but should, Andersen claims, be combined with Georges Sorel's views on violence, Gustave Le Bon's mass psychology, Michel Foucault's theories of discourse, Aleksandr Dugin's emphasis on ethnos, tradition and being, Curtis Yarvin's (Moldbug's) ideas on the relations between groups and ideas, Peter Sloterdijk's thoughts of thumos (the pursuit of glory); and Carl Gustav Jung's, Julius Evola's, and J.R.R. Tolkien's work on myth and blood. Above all, to establish a genuine deep right and plant the seeds that will bring forth the New Man, fascism needs to base itself on spirit and culture: 'In order to make a definite and lasting mark we need music, fiction, poetry and art that convey our myths and ideals. ${ }^{9}$

\footnotetext{
Andersen, Rising From the Ruins, 6-12.

Ibid., 9 .

Ibid., 302 .

Ibid., 300 .

Ibid., 301, 113 .
} 


\section{Fascist Fiction}

There is a rich body of astute scholarship on fascist art, sculpture, literature, film, theatre, and architecture during the interwar years, as well as under the fascist regimes in Fascist Italy and National Socialist Germany. ${ }^{10}$ There are also seminal works on avant-gardist fascist culture, visual art and literature in early twentieth century France, ${ }^{11}$ Romania, ${ }^{12}$ Croatia, ${ }^{13}$ and Japan; ${ }^{14}$ on individual poets (e.g. Marinetti, Pound, Hamsun) $;^{15}$ and on national socialist literature

10 These studies include Mabel Berezin, Making the Fascist Self: The Political Culture of Interwar Italy (Cornell, NY: Cornell University Press, 1997); Aristotle Kallis, The Third Rome, 1922-1943 (New York: Palgrave MacMillan, 2014); Marla Susan Stone, The Patron State: Culture and Politics in Fascist Italy (Princeton University Press, 1998); Stephen Gundle, Mussolini's Dream Factory (New York \& Oxford, Berghahn Books, 2013); Medina Lasansky, The Renaissance Perfected: Architecture, Spectacle, and Tourism in Fascist Italy (University Park, PA: Penn State University Press, 2005); Eric Michaud, The Cult of Art in Nazi Germany (Stanford, CA: Stanford University Press, 2004); Peter Adam, Art of the Third Reich (New York: Harry N. Abrams, 1995); Jonathan Petropoulos, Art as Politics in the Third Reich (Chapel Hill, NC: University of North Carolina Press, 1999); Simonetta Falasca-Zamponi, Fascist Spectacle: The Aesthetics of Power in Mussolini's Italy (Berkeley \& Los Angeles: University of California Press, 2000); Hilmar Hoffmann, The Triumph of Propaganda: Film and National Socialism 1933-1945 (New York: Berghahn Books, 1997); Susan Tegel, Nazis and the Cinema (New York: Bloomsbury, 2005); Mattew Affron, Fascist Visions: Art and Ideology in France and Italy (Princeton, NJ: Princeton University Press, 1997); John Champagne, Aesthetic Modernism and Masculinity in Fascist Italy (London \& New York: Routledge, 2014); Jana Francesca Bruns, Nazi Cinema's New Women (Cambridge: Cambridge University Press, 20o9); Michael Kater, Culture in Nazi Germany (Yale University Press, 2019); Martin G Benjamin, The Nazi-Fascist New Order for European Culture (Harvard University Press, 2016); Anthony White, Italian Modern Art in the Age of Fascism (London: Routledge, 2019); Roger Griffin, Modernism and Fascism: The Sense of a Beginning under Mussolini and Hitler (New York: Palgrave Macmillan, 2007).

11 Mark Antliff, Avant-Garde Fascism: The Mobilization of Myth, Art, and Culture in France, 1909-1939 (Durham, NC: Duke University Press, 2007); David Carroll, French Literary Fascism (Princeton, NJ: Princeton University Press 1994).

12 Marta Petreu An Infamous Past: E.M. Cioran and the Rise of Fascism in Romania (Chicago: Irvan Dee 2005).

13 Rory Yeomans, Visions of Annihilation: The Ustasha Regime and the Cultural Politics of Fascism, 1941-1945 (Pittsburgh, PA: University of Pittsburgh Press, 2013).

14 Alan Tansman, The Aesthetics of Japanese Fascism (Berkeley \& Los Angeles: University of California Press, 2009).

15 Cf., Ernest Ialongo, Filippo Tommaso Marinetti: The Artist and His Politics (Vancouver: Fairleigh Dickinson University Press, 2016); Paul Morrisson, The Poetics of Fascism: Ezra Pound, T.S. Eliot, Paul de Man (Oxford \& New York: Oxford University Press, 1996); Tore Rem, Knut Hamsun: Die Reise zu Hitler (Berlin: Das Neue Berlin, 2016); Andrew Rankin, Mishima, Aesthetic Terrorist: An Intellectual Portrait (Honolulu: University of Hawaii Press, 2018). 
in interwar Norway, ${ }^{16}$ Denmark, ${ }^{17}$ and Sweden. ${ }^{18}$ With his pivotal study Male Fantasies ([1978], 1989), Klaus Theleweit broke new ground by his careful analysis of masculinity and violence based on popular - rather than highbrow - fascist(oid) or 'proto-fascist' literature, investigating more than $25^{\circ}$ Freikorps novels from the 1920s, many of which sold in hundreds of thousand copies. However, studies of contemporary fascist culture remain sparse. There are a few outstanding studies of contemporary fascist fashion, (e.g., Cynthia Idriss Miller's The Extreme Gone Mainstream, 2017), and popular music, (e.g., Benjamin Teitelbaum's Lions of the North. Sounds of the New Nordic Radical Nationalism, 2017; Nancy Love's Trendy Fascism, 2016), ${ }^{19}$ but there are hardly any studies of contemporary fascist fiction beyond a few works on William Pierce's trend setting race-war novels The Turner Diaries and Hunter. ${ }^{20}$ Contemporary fascist literature in other languages has, to the best of my knowledge, received less attention. ${ }^{21}$

This essay investigates the role of violence and passion in contemporary Swedish-language fascist fiction that seeks to appeal to the hearts and minds of its readership. Contemporary fascist fiction may be melodramatic, nostalgic, utopian, epic, or romantic, but universally employs passion and violence. Currently, there is a surge of fascist literary production with dozens of

16 Dean Krouk, Fascism and Modernist Literature in Norway (Washington University Press, 2017).

17 Ole Ravn, Dansk nationalsocialistisk litteratur 1930-45 (Berlingske Forlag 1979).

18 Bibi Jonsson, Bruna pennor: Nazistiska motiv i svenska kvinnors litteratur (Stockholm: Carlsson, 2012).

19 Cynthia Idriss Miller's The Extreme Gone Mainstream (Princeton \& Oxford: Princeton University Press, 2017); Benjamin Teitelbaum's Lions of the North: Sounds of the New Nordic Radical Nationalism (Oxford \& New York: Oxford University Press, 2017); Nancy Love's Trendy Fascism (New York: SUNY, 2016).

20 Jonathan S. Cullick, "The Literary Offenses of a Neo-Nazi: Narrative Voice in "The Turner Diaries", Studies in Popular Culture 24, no. 3 (2002): 87-99; Brad Whitsel, 'The Turner Diaries and Cosmotheism: William Pierce's Theology,' Nova Religio: The Journal of Alternative and Emergent Religion 1, no. 2 (1998): 183-197; Terence Ball, Richard Dagger, 'Inside The Turner Diaries: Neo-Nazi Scripture,' Political Science and Politics 30, no.4 (1997): 717-718. Of course, Pierce's novels are analyzed in works on US white power culture too, including Mattias Gardell, Gods of the Blood: White Separatism and the Pagan Revival (Durham, NC: Duke University Press, 2003). In addition, there are recent works on apocalyptic literature in the US, including Jeffrey Kaplan, 'America's Apocalyptic Literature the Radical Right,' International Sociology 33, no. 4 (2018): 503-522.

21 There are good works on dystopian literature and European identity, including Ivan Strenski, 'Prospects for the Death of Europe: Islam, Christianity, the Future Identity of Europe,' Terrorism \& Political Violence 31, no. 3 (2020): 654-68o, and Per-Erik Nilsson, 'Fuck Autonomy: Neo-Orientalism and Abjection in Michel Houellebecq's Soumission,' European Review 27, no. 4 (1999): 6oo-614. 
Swedish-language titles published in different genres, including short stories, romance, crime, thriller, fantasy, sci-fi, poetry, and historical drama. Their works are disseminated by fascist publishers (e.g., Logik, Arktos) and online vendors (e.g., Midgård, AlternaMedia, Nordfront), as well as by mainstream online retailers (e.g., Adlibris, Bokus, Amazon). While fantasy and historical drama rank among the more popular genres with bestsellers such as Slavarnas tidsålder [The Age of the Slaves] and Gökinvasionen [The Cuckoo Invasion], trending titles of today tend to be crime fiction written in the style of Nordic Noir from a fascist political perspective.

The first crime fiction to make a breakthrough was Vargarna [The Wolves], published in 1996 under the pseudonym Karl Pettersson by Åke Bylund, lead singer in the prog rock band Mörbyligan, who went from socialist to national socialist, and joined the white power music scene with tributes to Per Engdahl and the Norse gods. Vargarna is set in the near future when Sweden has become Internationalia, a client state of the anti-national European Union, under the leadership of an anti-white regime backed by the Antifa paramilitary New Loving Generation. Bylund's Sweden is a decaying Mad Max world in which innocent white women, honest white workers and honorable white seniors are fair game to violent nonwhite perverts. The protagonists are a wolf pack of militant white nationalist dissidents. As in The Turner Diaries, the underground network evaded the regime's troops that brought all other political dissidents of patriotic persuasion to concentration camps, and then challenges the powers-that-be in a series of violent confrontations. Eventually, the wolf den is located and besieged by government agents. 'We are a small pack but we are wolves, Nordic wolves', says the chief of warriors to his beleaguered wolf clan and raises a horn of mead for the Free North. 'We will not rest before we've won - or lost.' The wolf pack manages to escape and joins the national resistance movement that has taken power in the province of Dalarna from where the national liberation of Sweden will take place (as it often does in Swedish ethno-nationalist imagination). ${ }^{22}$

Vargarna is explicitly Third Positionist (i.e., adheres to socialist fascism/ national bolshevism) and Bylund repeatedly scorns rightwing nationalism as a fallacy that betrays the true interest of the racial nation. Not so in

22 Karl Pettersson [a.k.a. Åke Bylund], Vargarna (Visby: Frøya förlag, 1996). Among Swedish nationalists, Dalarna is construed as a province of fiercely independent rebels. The Dalarna Adventure of Sweden's Founding Father King Gustav I Wasa is part of Sweden's national heritage mythos, and the Province of Dalarna is the site from which the Swedish war of liberation against the tyranny of the Danish King Christian II once began. It is not a coincidence that the Nordic Resistance Movement has chosen Dalarna as its base. 
Vedergällning [Retaliation] by (pseudonym) Krister Falk (2003). To Falk, it is not the working-class but the bourgeoise middle-class of the homeowners' associations and the steering committees of the prosperous gated communities that will pave the way for national liberation. This novel is also set in the near future, a few years from now. The honorable white Folk has been betrayed by the social democratic government and their masters in the economic and intellectual elites. The protagonist is not a wolf pack but a lone wolf, Lars, who initiates a one-man race-war after his pregnant wife had been gangraped and murdered by a band of black barbarians who celebrate when acquitted in court by the politically correct jurors. ${ }^{23}$

Lars realizes that black on white crime is part of the invading colonizers' tactics to humiliate the 'indigenous white population' and its 'feminized males' who no longer know how to fight. ${ }^{24}$ Lars was not going to let that happen. With a knife tucked into his boots, two pistols with homemade silencers in holsters over his muscular chest, hand grenades in belt, an automatic battle rifle in hands, and a balaclava over his distinctly Nordic face, he looked like a hero, he thought, when catching a glance of himself in the mirror reflection of his car's black glass, before embarking on a nocturnal shooting spree, killing black, Latin American and Muslim people in Hammarkullen, a stigmatized underclass area in Gothenburg. Eventually, Lars comes in contact with The Network, a web of nationalist underground resistance cells in the more affluent suburbs. Lars' contact guides him politically and gradually exposes the Jewish conspiracy behind the current mass-invasion that will replace the land's indigenous white folks with racial aliens. 'Now terror will be answered by terror', explained the Sage of the Network, with implied reference to Hitler. Falk invites his readers to enjoy the violent clashes between the Aryan warriors and their racial enemies which culminates when Lars 'slaughters the pig', i.e., kills the treasonous Prime Minister, followed by the nationalist victory, and the heroic funeral of Lars who, much like Earl Turner of The Turner Diaries, fell in the final battle. ${ }^{25}$

A widely acclaimed fascist writer is journalist Henrik Johansson, whose debut crime fiction Sista steget [Final Step] (2004), ends with a suicide bombing that destroys the headquarters of the Swedish Armed Forces, another detail we recognize from the The Turner Diaries. In the Final Step, we meet two lone wolves, the truck driver Kenneth and a single mother. Inspired by vigilantes who kill Roma people, Kenneth takes out his revenge on politicians and

23 Krister Falk, Vedergällning (Linköping: Nordpocket, 2003).

24 Falk, Vedergällning, 56, 108.

25 Falk, Vedergällning. 
nonwhites when his elderly parents are robbed and killed by racial strangers. He bombs a police passport office that issues Swedish passports to children of Arab immigrants, and a civic center that organizes a Day of Tolerance in response to immigrant crime. In the commotion caused by the bloody bombings, Kenneth sets out on a 'mulatto hunt' at a shopping mall that is described in gruesome detail. White fascist lone female wolves are still relatively rare, both in real life and fascist literature. But there are exceptions, such as the single mother in the Final Step. She has no name, age, or personal history. Her one function is her motherhood of which she is deprived when her daughter kills herself after having been raped by nonwhite 'apes'. Representing the despair of all white mothers in multicultural Sweden, and the cleaning violence unleashed when Mother Svea [the Swedish nation] finally awakens, the single mother exacts revenge by stabbing young adult nonwhite males to death with a chef's knife. 'It was so easy', the narrator explains. She entered tenement houses, knocked at the doors to homes with non-Swedish residents selected by the names of their apartment doors, went in and killed the sons in front of their horrified families. One chop in the stomach, one in the groin, one in an eye, and then slit the throat. One, two, three, 'fucking ape', four; out of the door, next floor, there you go. ${ }^{26}$

Johansson was awarded a fascist book prize for a short story originally published in Svenska roster: Noveller av den tystade majoriteten [Swedish voices: Short stories by the silenced minority] (2007) ${ }^{27}$ and republished in Johansson's collection of short stories, Vattnet under broarna [Water Under the Bridges] (2010). ${ }^{28}$ Johansson's awarded contribution, 'Ett samtal med psykologen' ['A conversation with the psychologist'], tells the story of a single father's rightful revenge on three black rapists who defiled his daughter, and the justice system that let them walk. The father visits a psychologist and describes in grisly detail how he buried the rapists alive in coffins, for them to die, slowly and in torment. When the psychologist realizes that this was the case where the court went on his testimony and acquitted the perpetrators, it is too late. He wakes up with an aching head and bloody scalp, realizing that he cannot move more than a few inches in any direction. It's totally dark, it smells of earth and sawdust. He realizes that he lies in a coffin and screams in horror. Above his grave, the father smiles when he hears the dampen sounds of agony from deep

26 Henrik Johansson, Sista steget (Linköping: Nordpocket, 2004).

27 Henrik Johansson, ed., Svenska röster: Noveller av den tystade majoriteten (Nordiska förlaget, 2007).

28 Henrik Johansson, ed., Vattnet under broarna (London \& Stockholm: Arktos, 2010). 
underground, leans back against a house wall, pulls out a list of names, crosses out the psychologist and studies the names of those who remain. ${ }^{29}$

With Flickan som jagades av elden [The Girl Who Was Chased by Fire], a title obviously referring to the second volume in the Millennium series by Stieg Larsson, ${ }^{30}$ Sebastian Bjurman of the now defunct radical nationalist projects Pegida and the Swedes' Party, suddenly made an impact in the radical nationalist landscape. The crime fiction tells the story of the protagonist Sandra who is raped by celebrated anti-fascist immigrant Achmed Mustafa. Everything she believes in is turned on its head. The establishment, the anti-racist community, and all her friends take exception to her. Seeking revenge, she wants to buy a gun from a criminal immigrant, but is fooled, robbed, beaten, and about to be raped again when she is miraculously saved by a 'real man', a true man, a Swedish man, a white national socialist man, Alexander, a cleanshaven, well-mannered, muscular hero. He helps her contextualize her experience by unmasking the evilness of the anti-white System and guides her to adopt fascist truth. The national socialist hero helps the protagonist take revenge on the rapist and the System before they escape with the help of a police officer sympathetic to their cause. Sandra realizes the necessity of violence. 'Not even murder is necessarily evil or frightening; on the contrary, it may be self-defense' and serves the cause to secure the liberty and dignity of the white Nordic race. ${ }^{31}$

\section{Fascist Nordic Noir}

The crime novels briefly discussed above are not the only Swedish-language titles, but examples of contemporary fascist crime fiction written in the style of Nordic Noir. ${ }^{32}$ As in the pioneering Wallander series by Henrik Mankell and the Martin Beck series by Maj Sjöwall and Per Wahlöö, fascist Nordic Noir investigates the shadowy underworld of modern society, and critically address social issues, but from a fascist political perspective. Stylistically, fascist Nordic Noir keeps the plain language and dark tone of the genre but may feature less complex and multilayered storylines and less melancholic protagonists. As

29 Henrik Johansson, 'Ett samtal med psykologen,' in Vattnet under broarna, ed. Henrik Johansson (London \& Stockholm: Arktos, 2010), 7-49.

30 Sebastian Bjurman, Flickan som jagades av elden (Helsingborg: Logik förlag, 2017). The second volume in the Millennium trilogy was The Girl Who Played with Fire.

31 Bjurman, Flickan, 105.

32 Nordic Noir is sometimes referred to as Scandinavian Noir to exclude Finnish and Icelandic authors which I do not see any reasons for doing. 
in the wider genre, murder, rape, misogyny, and racism reflect systemically entrenched dynamics, but again interpreted from a white fascist viewpoint. The narrative is set in the decaying world of multiculturalism, political correctness, and meaningless consumerism, with the once great Swedish nation aimlessly drifting towards destruction. White majoritarian Swedes are positioned as repressed and depressed, bereft of their aboriginal homeland, mocked by the intellectual elite, silenced by the PC media, abused by racial strangers, and betrayed by the political class, in a society contemptuous of everything Swedish, including Swedish history, values, people, and traditions. Elderly white Swedes are robbed and mocked, beautiful young blonde Swedish women are violated and raped, white Swedish men are feminized and ridiculed. Any deviation from what is healthy and natural is elevated at the expense of the hardworking white heterosexual man to the public acclamation of anti-racist white self-haters and the gay lobby, two factions held in great contempt by the invading racial strangers who benefit from their treason. A common feature of fascist noir is violent rape. Of course, black sexual desecration of innocent white women is a figure of longstanding prominence in the history of racism, in which black male hands on white female skin recurrently has sparked violent reaction and set the stage for the entry of the valiant knight to come at her rescue. ${ }^{33}$

In fascist crime fiction, the righteous patriots are few but honorable. The stories are typically spun from below, from the perspective of the white working-class or lower middleclass man, or (more rarely) woman, the white self-made small business owner (always a man), or the white high-school student (male or female), and depicts his or her awakening, often triggered by the straw that finally broke the camel's back. The protagonist is typically a decent young white man or woman, who initially believes what he or she has been told: that all cultures are equal, races do not exist, and fascism is evil. By being exposed to some shockingly violent crime, rape, assault, or murder committed by racial strangers protected by the corrupt system, the protagonist wakes up to the realities of the ongoing white genocide and realizes the need to take action. Seeking revenge, the protagonist learns how to be a man, or meets her hero, and is gradually introduced to fascist political convictions. In the first stages, he or she typically rejects what she/he sees or hears and becomes convinced only by embarking on a critical search for truth. He or she then sees the light, and converts to fascism, something the author most

33 Recall, for instance, the impact of the epic silent movie The Birth of the Nation (1915) and its portrayal of the heroic white knights coming to the rescue of the agonized white female victims of savage black rapists. 
likely hopes that his reader will also do. As William Pierce explained when we sat at his home on the outskirts of Hillsboro, West Virginia and discussed his novels The Turner Diaries and Hunter:

This is the way to teach people. Write novels, write plays, write film scripts, because a person not only experiences the actions of the protagonist, but if you have the protagonist in decision-making situations, when he has some sort of a conflict that he has to resolve, the reader, or the viewer, undergoes the same thought processes, and then you can carry the audience along, to educate them, to get them to change their minds, to get them to see things the way the protagonist learns to see things. ${ }^{34}$

In the course of the protagonist's journey, the reader of fascist crime fiction may be introduced to white nationalist classics, (e.g., The Passing of the Great Race by Madison Grant; The Decline of the West by Oswald Spengler; For My Legionaries by Corneliu Zelea Codreanu; My Awakening by David Duke; Might is Right by Ragnar Redbeard; and White Power by George Lincoln Rockwell), and revolutionary white racist heroes whom the System desperately seeks to prevent white people from knowing, including Robert Jay (Bob) Matthews (who launched the first post-world war two white nationalist guerilla campaign in the Pacific Northwest in the early 1980s), Joseph Paul Franklin (the white racist lone wolf serial killer to whom Pierce dedicated Hunter), and David Lane, who coined the holy Fourteen Words: 'We must secure the existence of our people and a future for white children' to galvanize white resistance against the ongoing white genocide.

The protagonist of fascist noir is not only schooled in political philosophy, but in the way of the warrior. Having initially taken exception from violence, he finally has enough of being a feminized weakling. The warrior instincts that are embedded in the nature of the white race is eventually rekindled and the protagonist learns to master the art of killing, how to build a bomb, get away with murder, travel unnoticed, and the basics of militant underground tactics. Reflecting ongoing white nationalist debates about whether white unity should be in organization or purpose, if white resistance at this time and stage is best wrought by centralized command or leaderless resistance, if white racial survival may be secured by ousting the current administration or only by bringing on the apocalypse, fascist crime fiction may feature the heroic accomplishments of some white nationalist liberation front or the lone white wolf

34 William Pierce, interview with author, Hillsboro, West Virginia, tape recorded, March 19, 1997. 
assassin. In many plots, the author discusses the pros and cons of both ways of waging race war, and how they may be combined.

The Turner Diaries and Hunter may be required reading among contemporary white fascist radicals, and both have been translated to Swedish by Magnus Söderman, a veteran fascist organizer and author who has introduced several Klan, Cosmotheist, Identity Christian, and Odinist thinkers to a Swedish language audience, and who is currently involved with the Casa Pound inspired Det fria Sverige [The Free Sweden] project to build fascist social centers as nodes of white fascist resistance and islands of refuge from the ongoing white genocide. ${ }^{35}$ While fascism is a radical nationalism (Griffin's ultranationalism) it has always transcended national borders, and The Turner Diaries and Hunter have been entangled with the history of Swedish fascism and the personal lives of violent radical nationalists, including white racist serial killer Peter Mangs who was 'mesmerized' by the former and adopted the tactics of Joseph Paul Franklin, whom he learned about through the latter. ${ }^{36}$

Of course, The Turner Diaries and Hunter are fiction, and so are the works in the fascist noir genre written by Swedish-speaking authors. As a precaution, possibly to serve the dual objective to avoid charges of incitement to racial hate crime, and to boost the Final Step, the book he was talking about at that moment, Henrik Johansson pointed out that 'it is not a manual I wrote, but entertainment pure and simple' with the intent of contributing to a 'nationalist culture' based on reality and sound morals in contrast to the deranged popular culture of his time. ${ }^{37}$ As Johansson explained to Joakim Andersen in

35 Andrew Macdonald (a.k.a. William Pierce), Turners dagböcker, trans. Magnus Söderman (Logik förlag, 2009); Andrew Macdonald (a.k.a. William Pierce), Jägaren, trans. Magnus Söderman (Logik förlag, 2009); Det fria Sverige, https://www.detfriasverige.se/. Magnus Söderman's bibliography includes, Uppmarsch mot Ragnarök (Stockholm: Nationellt Motstånd förlag, 2009,); Unbroken Warrior: The Richard Scutari Letters (co-authored with Henrik Holappa) (Stockholm: Nationellt Motstånd förlag, 2011); Till Värn för Norden (Logik förlag, 2011); Den trotsiga (Logik förlag, 2013); Rasist, javisst? (Motgift, 2015); Terrorism (Motgift, 2015); Fästning Europa (Motgift, 2015); Glimtar av liv (Motgift, 2016); Hell seger! (Motgift, 2017); 2016: Ett avgörande år (Motgift, 2017); Att förstå alternativhögern (Logik Förlag, 2017).

36 Mangs sought to ignite a race war by shooting to kill Black, Muslim, and Roma Swedes in the city of Malmö between the years 2003 and 2010 and is the most politically conscious white fascist lone wolf serial killer Sweden has seen so far. For scholarly work on Mangs, see Mattias Gardell, Raskrigaren: Seriemördaren Peter Mang [The Race Warrior: Serial killer Peter Mangs] (Stockholm: Leopard, 2015); Mattias Gardell, 'Urban Terror: The Case of Lone Wolf Peter Mangs,' Terrorism and Political Violence 30, no. 5 (2018): 793-811, https://doi.org/10.1080 lo9546553.2018.1444796.

37 Henrik Johansson interviewed by Björn Björkqvist about 'Sista steget', Realisten, February 3, 2005 . 
a Motpol article, 'If I were to write about gang rape it would be quite imbecilic to let the rapists be white Swedish men, as I know that [such a scenario] would not reflect reality. ${ }^{38}$ Addressing Stieg Larsson, Johansson claims that a story about a strong feminist female hacker who fights against white Swedish chauvinist males lacks every sense of credibility, and regrets that the author of The Millennium Trilogy allowed his political sympathies to shine through and destroy the narrative. To Johansson, 'credibility is key' to crime fiction, 'not to be politically incorrect but to be honest. ${ }^{39}$ As an illustration of his argument, Johansson points to his short story Smittan [Contagion] from 2010, which is about an artificially produced virus designed by Robert Mugabe to eliminate all white people from the face of the earth. As the pandemic virus harvests millions of white lives in the Western world that plunges into chaos, the Arab, Muslim, and Black people who had been welcomed as asylum seekers and migrants into the white heartlands of Europe, turn against their weakened host populations and kill, rape, torture, and ransack every white they encounter in a racial slaughter of apocalyptic proportions. At the very last moment, the sick and wounded white people who despairingly seek a way out of the inferno are reached by a radio broadcast from Russia, addressed to 'all you whites who survived the infection but lost your countries to the very same people whom you have sheltered': 'Your countries may be lost, but not your people [because] Russia is no longer the land of the Russians. We will share it with you as a new homeland of all white people in the world. 40

Of course, whiteness is not a product of nature but of classification. There are no given criteria by which certain people are classified as white and others not. Whether a particular people or person will be included or excluded as white varies according to time, place, context and perspective. ${ }^{41}$ To include Russians as white, and look at Russia as not only $a$ but the white homeland, as did Johansson, would not necessarily be or have been acceptable by fascists of other times or places. William Pierce followed in the footsteps of his political mentor, American Nazi Party founder George Lincoln Rockwell, in expanding the borders of whiteness to include Russians, Poles, Ukrainians, and

38 Joakim Andersen, 'Intervju med Henrik Johansson,' Motpol, January 9, 2011, https://motpol. nu/oskorei/2011/o1/og/intervju-med-henrik-johansson/.

39 Andersen, 'Intervju med Henrik Johansson.'

40 Henrik Johansson, 'Smittan, in Vattnet under broarna, ed. Henrik Johansson (London \& Stockholm: Arktos, 2010).

41 Mattias Gardell, 'Rasstaten och dess försvarare: Om vithet, nationalsocialism och vitmaktkultur i Förenta staterna,' in Brunt, Nationalistisk och nazistisk mobilisering i vår närmaste omvärld under efterkrigstiden, ed. Mats Deland and Charles Westin (Stockholm: Atlas, 2006). 
other East-European or 'Euroasian' peoples (to borrow a term from pioneering post-Second World War fascist reconstructionist Francis Parker Yockey). ${ }^{42}$ Yet, Pierce and Rockwell were caught up in a Cold War context in which Russians hardly were allies, much less identifiable as of the same people and kind.

Johansson's pro-Russian perspective has not been unanimously accepted in the political landscape of Swedish fascism. From a national Swedish perspective, the Russian Bear has not always been seen as an ideal neighbor, and far from all Swedish fascists have recognized an ally in Putin's Russia. When war broke out in the Donbass region of eastern Ukraine in 2014, a section of Swedish fascists (including the above-mentioned Söderman) organized support to the Volunteer Ukrainian Corps and the Azov Battalion with some thirty Swedes joining Ukrainian paramilitary militias as volunteer fighters. However, the Swedish Resistance Movement (today the Swedish section of the Nordic Resistance Movement, NMR) disagreed, and aligned with Russia and the Russian separatist militias in Ukraine. At least three NMR members received military training by Partizan, an urban warfare training center associated with the Russian Imperial Movement that send volunteers to Russian paramilitaries in Donbass.

The ambivalent attitude towards Russia is reflected in Perfekt Storm by Arne Weinz, which was published in $2019 .{ }^{43} \mathrm{~A}$ war thriller more than a crime fiction, Perfekt Storm is set in 2027 when the Muslim Brotherhood literally invades Sweden by a naval fleet carrying Muslim elite troops. In preparation for the armed assault, Muslims had trickled into Sweden for years, increasing their numbers through high birthrates, and established Jihadist strongholds in Muslim controlled no-go zones dotted across the country. Assisted by this fifth column of poorly trained but highly motivated jihadi warriors, the Muslim Brotherhood elite force rapidly gain control over most of Sweden and instill a reign of terror. Sweden's cultural heritage, including its churches, castles, operas, theatres, museums, beer halls, and old city quarters, are bombed to pieces and replaced with mosques, bazaars, and Muslim military academies. Having a beer, a pet dog, or a snus ${ }^{44}$ is criminalized. Dissidents, leftists, and multiculturalists are publicly executed; traitors could not be trusted. Based in the countryside, pockets of Swedish patriots launch an armed resistance, and are joined by migrant communities with an inherent hatred of Islam seeking

42 Francis Parker Yockey, Imperium: The Philosophy of History and Politics (Wentzwill, MO 2011 [1948]); Kerry Bolton, Yockey: A Fascist Odyssey (London: Arktos, 2018).

43 Arne Weinz, Perfekt Storm (n.p.: Global Village, 2019).

44 A Swedish moist powder steam-pasteurized tobacco product placed in upper lip for extended periods. 
to exterminate the Muslim brutes, e.g., Serbs, Croatians, Assyrians, Syrians, and Armenians. Initially disgusted by the thought of ethnic cleansing, a Swedish resistance commander admits that the raging fires that consumes thousands of screaming Muslim civilians trapped in multi-story housing complexes in the underclass areas of Southern Stockholm actually looks beautiful, as the blazing flames are reflected in the snow and reminds him of burning candles on a birthday cake. ${ }^{45}$

Despite exceptionally brave and intelligent fighters, the alliance of Swedes and honorary Swedes cannot defeat the massive Islamic occupation forces on their own. Fortunately, the no less anti-Muslim Russians come to their rescue. However, in contrast to Johansson's short story, the Russians do not act on altruistic grounds but with geopolitical motives. They seize the opportunity to transform the Baltic Sea into a Russian inland sea. By the end of the day, the peace agreement suggested by the United Nations is accepted by the warring parties, and Sweden is split in three zones, controlled by Muslims, Russians and Swedes respectively. Bad, but not as catastrophic as initially feared. Definitely, there is hope for national survival and rebirth; especially since the new government of Sweden thenceforth is run as a corporation with a CEO and a Board of Directors responsible to the major share-holders (the productive elite of the people), and not a corruptible government responsible to everyone and no one, as in a democracy based on the fallacy of equality. Fortunately, 'the corporate sector will never be democratized', Weinz assures his readers, as everything is about efficiency, and disloyal elements standing in the way of progress are immediately cleared. ${ }^{46}$ Law, order, and homogeneity are reestablished in the Kingdom, as Islam and the free press are banned, and leftists, Muslims, and dissidents neutralized, deported, or executed.

\section{Conclusion: The Politics of Passion}

Fascist Noir is characterized by a passionate celebration of violence, an element that Klaus Theweleit also found in the Freikorps literature and held central to the attraction of fascism itself. Fascist language, Theweleit found, appears to be unified around two main features. When fascists write of the everyday, their relations to themselves, their work, or their sensibilities, their language is meaningless, voided, aborted; when their writing is associated with violence in pursuit with world-historic missions, political foes and inferior

45 Weinz, Perfekt Storm, 319.

46 Ibid., 418. 
races, depraved beasts and white sisters, their language is animated, intense, alive. ${ }^{47}$ This feature reappears in contemporary fascist writing, suggesting a relation between violence, life, and passionate love. To fascist conviction, life is struggle and the absence of struggle is death. In fascist desire, Eros as the libidinal life force stands against Thanatos, the god of (peaceful) death, only in the sense that reduced tension and conflict means fading out and ultimately dying. In Freudian analysis, Thanatos is the death instinct that stands opposed to Eros, the life instinct. In Beyond the Pleasure Principle, Freud sought a way to bring the antithetical polarities between life and death instincts in relation to each other, even tracing the one to the other. ${ }^{48}$ Everything living ultimately dies from causes within itself, Freund reasons, suggesting that 'the goal of all life is death. ${ }^{49}$ Violence and aggression are self-destructive energies redirected outwardly toward external targets, Freud argues, finding in sadism an alloy between eroticism and death. Even 'where it emerges without any sexual purpose, in the blindest fury of destructiveness', Freud later writes, 'we cannot fail to recognize that the satisfaction of the instinct is accompanied by an extraordinarily high degree of narcissistic enjoyment, owing to its presenting the ego with a fulfilment of the latter's old wishes for omnipotence. ${ }^{50}$ In Civilization and its Discontents, Freud suggests that the outcome of the 'mutually opposing action' of Eros and Thanatos is of world dominion proportion. Written in 1930, when National Socialism began to assert itself as a political force to be reckoned with, Freud's tone in Civilization and its Discontents is pessimistic. Identifying civilization as a 'process in the service of Eros' whose purpose is to realize 'the unity of mankind,' Freud found its project jeopardized by its rival, man's natural aggressive instinct. 'The meaning of the evolution of civilization is no longer obscure to us,' Freud states, but '[re]presents the struggle between Eros and Death, between the instinct of life arid the instinct of destruction, as it works itself out in the human species. This struggle is what all life essentially consists of, and the evolution of civilization may therefore be simply described as the struggle for life of the human species. ${ }^{51}$

To the extent that violence and aggression in fascist literature is passionate, it cannot only be seen as opposed to Eros, but rather as an instinct imbued by eroticism and love. 'Fascist writing itself', Theweleit observes, 'makes quite

47 Klaus Theweleit, Male Fantasies. Vol. 2, Male Bodies: Psychoanalyzing the White Terror (Minnesota: University of Minnesota Press, 1989), 347ff.

48 Sigmund Freud, Beyond the Pleasure Principle (London \& Vienna: The Psycho-Analytical Press 1922), 67-70.

49 Freud, Beyond the Pleasure Principle, 47.

$5^{\circ}$ Sigmund Freud, Civilization and its discontents (New York: Norton \& Co, 1962 (1930)), 68.

51 Freud, Civilization, 69. 
deliberate associations between the protagonists' act of destruction and acts of love and self-creation. ${ }^{52}$ In his 1922 essay, Der Kampf als inneres Erlebnis [Battle as an Inner Experience], Ernst Jünger draws a parallel between war and love, arguing that the lust of blood in its intensity is equivalent only to Eros: 'The lust of blood hangs over the war like a red storm-sail over a black galley: in its boundless momentum it is comparable only to love. ${ }^{53}$ Thus, our analysis should not stop at identifying violence and aggression as forces of destruction and death, but look at destructivity's productivity, and the life-bequeathing aspects of death, which, I would argue, is at the core of fascism's urge for national rebirth. Only apocalyptic violence will create the conditions for the rise of the New World and the New Man; death is the cradle of life. Marking war and aggression masculine, and untainted violence (as opposed to tainted violence) a male-to-male task between (real) men, never aimed at (real) women (whores and traitors exempted), war is thereby elevated to the status of the principle of reproduction. Jünger wrote, 'War is not only our father, it is also our son. We have begotten him and he has begotten us. ${ }^{54}$ War as the Father and Son makes war akin to God, as God is the Father and Son. ${ }^{55}$ This makes the children of God children of war; the agents of war agents of God; the palingenetic mythos of fascism a vision of 'a new heaven and a new earth,' and the voice of fascism a promise: 'Behold, I make all things new' (Rev 21:5).

Reproduction and rebirth, fascism claims, do not really require women, not in any active role. With notable exceptions (e.g., Sandra in The Girl Who Was Chased by Fire), the emblematic protagonist in fascist fiction is a man or a band of men, a Männerbund. If the male protagonist has a family, a wife, mother, daughter, they are typically killed already in the introduction. By being killed, an act that does not require her saying much, the main role of the female character is over, except as a motif for revenge or metaphorical representation of the defiled nation. Her death sets the plot in motion, and the protagonist free to focus on his main mission, the violent destruction of the murderers and what they represent (blackness, Jewishness, Muslimness, or any other otherness and

$5^{2}$ Theweleit, Male Fantasies, 385 .

53 Ernst Jünger, 'Der Kampf als inneres Erlebnis,' (1922) in Sämtliche Werke, vol. 5 (Stuttgart: Klett, 1960-1965), 11-108. The analysis of Jünger's Der Kampf is indebted to Oliver Kohn, 'An Aesthetics of the Unbearable: The Cult of Masculinity and the Sublime in Ernst Jünger's "Der Kampf als inneres Erlebnis", Image \& Narrative 14, no. 3 (2013): 141-150.

54 Jünger, 'Der Kampf', 14.

55 We are all children of God, 'born not of the will of man but of God'. Of course, God then incarnate in flesh and made His dwelling among us. 'For God so loved the world, that he gave his only begotten Son, that whosoever believeth in him should not perish, but have everlasting life' (John 1:13-14; John 3:16). 
uncleanliness). In Warrior Dreams, James Gibson's seminal study on violence and manhood in post-Vietnam popular culture of the early 199o's, the warrior hero in American film is a man set apart. ${ }^{56}$ As in fascist noir, the hero's family, if there is one, his wife or children, are typically killed (MadMax, Lethal Weapon) or nearly killed (Patriot Games). The hero acts alone, with a partner or with a tribe of male warriors. If he belongs to an organization, he will not abide by their regulations but creates his own rules of engagement to serve a Higher Justice (Dirty Harry; Death Wish). He always fights for righteous American values but is typically frustrated or betrayed by representatives of the System (Rambo III; Clear and Present Danger; Black Berets). Substitute American values with white nationalist values and the System with politically correct multiculturalism, and the similarities to fascist fiction are obvious. Fascist fiction is not necessarily that different from mainstream popular culture, as evidenced by the fact that Braveheart arguably was the most popular movie in White Power United States in the late 1990s. ${ }^{57}$

In patriarchically conceived nationalist tradition, the nation is conventionally construed as a woman, in Swedish nationalism named Moder [Mother] Svea, and, therefore, as something that belongs to men. In radical nationalist narratives, the body of Moder Svea is penetrated by racialized others, illustrating the failure of her national guardians, the Swedish government, to perform as men, thus rendering their claim to be her protector and provider illegitimate. As she screams in anguish, real men should rush to her rescue, which is what the violence-prone radical nationalist warrior claims he is doing. In fascist self-conception, the militant activist is the white knight in shining armor. In fascist crime fiction, white beautiful blond Swedish women are recurrently raped and violated by racialized others. As observed by Karina Horsti, women are often represented as the embodiment of the nation in nationalist imagination, the 'openness' and softness of her body representing a weakness, a boundary for which violation and infection from the outside are constant threats. ${ }^{58}$

56 James W. Gibson, Warrior Dreams: Violence and Manhood in Post-Vietnam America (New York: Hill \& Wang 1994).

57 This observation is based on a multiyear ethnography of the White Power culture 1996-1999, the results of which were published as Mattias Gardell, Gods of the Blood: White Separatism and the Pagan Revival (Durham, NC: Duke University Press, 2003). I saw Braveheart over and over again in the homes of white power activists. Of course, Braveheart was immensely popular across the U.S. and beyond. It won five Academy Awards (Best Picture, Best Director, Best Cinematography, Best Makeup, and Best Sound Editing) and grossed \$75.6 million in the US; \$210.4 million worldwide in the monetary value of the time.

$5^{8}$ Karina Horsti, 'Digital Islamophobia: The Swedish Woman as a Figure of Pure and Dangerous Whiteness,' New Media \& Society 19, no. 9 (2017): 1440-1457. 
A metaphorical representation of the violated nation, the recurrence of the figure of the raped white woman in fascist noir provides the reader with ample opportunities to vicariously enjoy the pleasures of being a real man; a fascist man who comes to the rescue of the helpless woman in a blazing explosion of excessive violence, an eruption that destroys her aggressors and releases the salvaged woman's admiration for her hero.

The white fascist mission to save the endangered white woman, nation, and children by unleashing excessive violence allows him to rise above the mundane world of the plebeian commoner in consumerist society. It sets him apart in the more profound sense of being Holy and makes him a Crusader ready to sacrifice his life in pursuit of a divine mission. That the borders of real life and fiction may be blurred has frequently been illustrated by outbursts of fascist-inspired violence across western societies, including the self-proclaimed Templar Knight Anders Behring Breivik's bombing of the Norwegian government quarters in Oslo, and the massacre at a Labor Youth Party summer camp at Utøya. ${ }^{59}$ In Breivik's self-image he was a true hero, sacrificing himself to save the Norwegian nation and the Nordic race. ${ }^{60}$ Drawing on the psychoanalytical work of Peter Sloterdijk, Joakim Andersen points at Thumos as a driving force on par with Eros. Thumos is the pursuit of glory, which, to fascists, is integral to manliness. A culture without Thumos is an unmanly culture. When contemporary white fascists characterize Western society as feminized, they often refer to the supposed lack of Thumos. A man experiencing a violation of his dignity cannot, Andersen emphasizes, be bought; any attempt to bribe him exacerbates his fury. Accordingly, not being able to defend your woman and nation will publicly deprive a man of his manliness, of his Thumos, making him a worthless creature, a feminized weakling. Thumos is thus key to the warrior instinct fascism celebrates. ${ }^{61}$ The recurrent message inherent in contemporary fascist fiction is that a man who does not employ passionate violence to rid the nation from the dragon of politically correct multiculturalism and to put an end to the ongoing white genocide; a man who abstains from drawing his sword to protect the endangered white woman, is a man not set apart, i.e., an unholy man.

To Benito Mussolini fascism was a 'spiritual view of life'; an idealistic reaction to materialism, scientific positivism, simultaneously anti-capitalist and

59 Mattias Gardell, 'Crusader Dreams: Oslo 22/7, Islamophobia, and the Quest for a Monocultural Europe,' Terrorism and Political Violence 26, no. 1 (2014): 129-155.

6o Anders Behring Breivik, interviewed by author, Telemark prison, Skien, Norway, June 19, 2014.

61 Andersen, Rising From the Ruines, 113. 
anti-communist. ${ }^{62}$ Fascism invites its devotees to transcend the mundane and materialistic to become part of an evolving Faustian nation that will see the dawn of the New Era and the New Man arising out of the ashes of the cleansing flames of apocalyptic violence. Fascist fiction with its passionate celebration of violence, Eros, and Thanatos, Life, and Death, should not be underestimated as an avenue to turn the heart of fascist desire on fire.

\section{Acknowledgements}

This study was supported by the Swedish Research Council, 2016-04758.

62 Benito Mussolini, La Dottrina del Fascismo (Roma: EnciclopediaItaliana, 1942). 